\title{
CHRIST'S EVOLUTION OF MORAL UPBRINGING IN THE LIGHT OF LETTERS TO YOUNG PEOPLE BY POPES ST. JOHN PAUL II AND FRANCIS
}

DOI: http://dx.doi.org/10.12775/TiCz.2021.025

\begin{abstract}
The significant social, economic and cultural transformations taking place since the second half of the twentieth century reveal with increasing force that young people are diverging more and more from adults as far as ethics and morality are concerned. Contemporary reflection on morality is increasingly being expressed in the manifestation of individuals' rights. This is the view of both the Letter to the Young People Parati semper by St. John Paul II (1985) and the Post-Synodal Apostolic Exhortation Christus vivit by Pope Francis (2019). The above papal documents will become the starting point for answering the following question: What does Christ propose in terms of morality?

Man is capable by nature (in his heart) of recognizing good and evil. Morality is then bound to keeping the Law, which, while being positive, is limited in time. Man's coming to faith causes, as Pope Francis points out, the exhaustion of the Law's propaedeutic value and, thus, gives way to another authority. The Law is still in force (the commandments continue to exist), but it has no justifying power. The one who justifies is Jesus Christ. In this context, it is crucial to answer the question regarding the stage of moral maturation: do I still need the Law, or perhaps I am already living in the love and freedom of a child of God. These levels of morality cannot, as postulated by St. John Paul II in Parati semper and Francis in Christus vivit, be treated as separate or contradictory, because both are necessary. Hence, one cannot reject and despise the commandments and, at the same time, keep them, even though they are not absolute, because salvation is in Jesus Christ!
\end{abstract}


Key words: moral education, shaping conscience, God as educator, biblical education, Parati semper, Christus vivit.

Streszczenie. Ewolucja wychowania moralnego w Chrystusie w świetle listów do młodzieży wystosowanych przez papieży Jana Pawła II i Franciszka. Dokonujące się w drugiej połowie XX wieku znaczące przemiany społeczne, ekonomiczne i kulturowe z coraz większą siłą ujawniają, że młodzież w obszarze etyki i moralności jest coraz mniej podobna do dorosłych. Współczesna refleksja nad moralnością coraz częściej wyraża się w manifestowaniu przez poszczególne jednostki przysługujących im praw. W takiej optyce mieści się zarówno List do młodych „Parati semper” św. Jana Pawła II (1985), jak również posynodalna adhortacja „Christus vivit” papieża Franciszka (2019). Przywołane dokumenty papieskie staną się punktem wyjścia do udzielenia odpowiedzi na pytanie: Co proponuje Chrystus na płaszczyźnie moralności?

Człowiek z natury (w sercu) może rozpoznawać dobro i zło. Moralność jest wówczas związana z zachowywaniem Prawa. Choć ma ono charakter pozytywny, to jest ograniczone w czasie. Dojście człowieka do wiary powoduje, jak wskazuje papież Franciszek, że Prawo wyczerpuje swoją wartość propedeutyczną i ustępuje miejsca innemu autorytetowi. Prawo obowiązuje w dalszym ciągu (przykazania istnieją), ale nie ma mocy usprawiedliwiającej. Tym, który usprawiedliwia, jest Jezus Chrystus. W tym kontekście kluczowe jest udzielenie odpowiedzi na pytanie o etap dojrzewania moralnego: czy potrzebuję jeszcze Prawa, a może już żyję w miłości i wolności dziecka Bożego. Nie można tych poziomów moralności - jak postulują św. Jan Paweł II w Parati semper i Franciszek w Christus vivit - traktować rozdzielnie czy przeciwstawnie, bo oba są konieczne. Stąd nie można odrzucać przykazań i nimi gardzić, ale zachowywać je, choć nie mają charakteru absolutnego, gdyż zbawienie jest w Jezusie Chrystusie!

Słowa klucze: wychowanie moralne, kształtowanie sumienia, Bóg jako wychowawca, wychowanie biblijne, Parati semper, Christus vivit.

Contemporary reflection on morality is increasingly being expressed in the manifestation of individuals' rights. "In the modern era," as Zdzisław Aleksander confirms in his research, "a revolution in thinking about man began, as part of which the idea of the individual's autonomy and right to freedom was emphasized. As a result, it was concluded that moral judgments are an expression of individual preferences and feelings." This allowed for the elevation of the human individual and

1 Z. Aleksander, Szansa na międzypokoleniowy dialog $w$ kontekście rozumienia słów z zakresu moralności przez współczesne podmioty edukacyjne, Gdańsk 2009, p. 193. 
the formation of the concept of an "autonomous moral subject," which is fairly closely linked to the moral degradation of the contemporary man of postmodern culture. The significant social, economic and cultural transformations taking place since the second half of the twentieth century reveal with increasing force that young people are diverging more and more from adults as far as ethics and morality are concerned. ${ }^{3}$

It is worth noting that for Christians, the true key and compass of moral evaluation is the Holy Bible. ${ }^{4}$ Hence, "if we [...] wish to go to the heart of the Gospel's moral teaching and grasp its profound and unchanging content," as St. John Paul II argued, "we must carefully inquire into the meaning of the question asked by the rich young man in the Gospel and, even more, the meaning of Jesus' reply, allowing ourselves to be guided by him. Jesus, as a patient and sensitive teacher, answers the young man by taking him, as it were, by the hand, and leading him step by step to the full truth." ${ }^{5}$ This is the view of both the Letter to the Young People Parati semper by St. John Paul II, ${ }^{6}$ written on the occasion of the International Year of Youth (1985), and the Post-Synodal Apostolic Exhortation Christus vivit to Young People and to the Entire People of God by Pope Francis (2019). ${ }^{7}$ The above papal documents will become the starting point

2 A. MacIntyre, Dziedzictwo cnoty. Studium z teorii moralności, Warsaw 1996.

3 S. Tykarski, "The evolution of modern marriage: From community to individualization. Theological reflection," Cauriensia. Revista anual de Ciencias Eclesiásticas 14 (2019), pp. 581-592 (DOI: https://doi.org/10.17398/2340-4256.14.581).

${ }^{4}$ M. Koszkało, "Bóg jako źródło moralności. Intuicje św. Augustyna w Wyznaniach 7.10-11 w kontekście dyskusji z tradycją starożytną, Verbum Vitae 39 (2021) no. 3 (DOI: https://doi.org/10.31743/vv.12827).

5 John Paul II, Encyclical Letter Veritatis Splendor Regarding Certain Fundamental Questions of the Church's Moral Teaching, Rome 1993, no. 8, https://www.vatican.va/ content/john-paul-ii/en/encyclicals/documents/hf_jp-ii_enc_06081993_veritatis-splendor.html (retrieved on September 16, 2021).

${ }^{6}$ Cf. idem, Apostolic Letter Dilecti Amici to the Youth of the World on the Occasion of International Youth Year, Rome 1985, https://www.vatican.va/content/john-paulii/en/apost_letters/1985/documents/hf_jp-ii_apl_31031985_dilecti-amici.html (retrieved on September 16, 2021).

7 Cf. Francis, Post-Synodal Apostolic Exhortation Christus Vivit to Young People and to the Entire People of God, Rome 2019, https://www.vatican.va/content/francesco/ en/apost_exhortations/documents/papa-francesco_esortazione-ap_20190325_christusvivit.html (retrieved on July 18, 2021). 
for answering the following question: What does Christ propose in terms of morality?

The papal statements addressed to young people show that both the Old Testament and the New Testament are eminently parenetic (from the Greek: $\pi \alpha \rho \alpha i v \varepsilon \sigma \iota \varsigma$, parainesis). ${ }^{8}$ The encouraging and didactic dimension of Jesus's New Testament pedagogy, although having its roots in the Old Testament idea of the Chosen People (Francis refers to Joseph, Gideon, Samuel, David, Solomon, Jeremiah or Ruth in Christus vivit), gives morality a completely different dimension. It should be made clear that Jesus is not giving a ready-made, comprehensive and structured treatise or lecture on morality, but He does speak on the subject on several occasions. His teaching, as Fr. Zbigniew Wanat claims, "does not bring any ready-made concept of conscience. It is characterized by referring to the category of the heart known to the interlocutors and by deepening its importance to moral life." It is worth noting that St. John Paul II invokes the heart 21 times in Parati semper, and Pope Francis does so as many as 64 times in Christus vivit. Christ's moral message runs from the Old Testament faithfulness to the law (Greek: vó $о$ ç, nomos - law) to the New Testament "being in Christ" (Latin: esse in Christo; Greek: einai en, menein - to permanently remain). Two levels stand out in the new view of the Christian: an ontic view, in which he is already constituted, and a moral view, in which he is in the process of becoming. ${ }^{10}$ It is, in a way, a transition from ontology to morality (from theology to praxis).

8 Cf. W. Cichosz, "Biblijne wychowanie parenetyczne. Od pedagogiki do pedagogii," ed. R. Czekalski, Studia Katechetyczne 8 (2012), pp. 243-253, https://bazhum.muzhp. pl/media/files/Studia_Katechetyczne/Studia_Katechetyczne-r2012-t8/Studia_Katechetyczne-r2012-t8-s243-253/Studia_Katechetyczne-r2012-t8-s243-253.pdf (retrieved on September 2, 2021). On the basis of the literature on the subject, we can say that parenesis means, above all, encouragement. It is also a kind of instruction, advice or admonition. In poetry, on the other hand, the term parenesis (e.g. parenetic poetry) denotes works of a didactic (journalistic and moralistic) character. See. W. Cichosz, Pedagogia wiary we współczesnej szkole katolickiej, Warsaw 2010, pp. 167-171.

9 Z. Wanat, Hipokrates i sumienie. Teologiczny aspekt formacji moralnej pracowników stużby zdrowia, Pelplin 2019, p. 104. In the context of the reference to the image of the heart, we must also recall Jesus's use of the figure of the eye.

${ }^{10}$ Cf. W. Cichosz, J. Lisica, "Przyczynek do chrystianologii moralnej św. Pawła $w$ świetle Listu do Rzymian 1-8, ed. J. Szulist, Studia Pelplińskie 46 (2013), pp. 31-48, https://depot.ceon.pl/bitstream/handle/123456789/7394/Przyczynek\%20do\%20chrystianologii\%20moralnej\%20\%C5\%9Bw.\%20Paw\%C5\%82a\%20w\%20\%C5\%9Bwietle\%20 


\section{SOME LEXICAL (SEMANTIC) REMARKS}

In order to present Christ's proposal in the area of morality, one must bear in mind that it is necessary to first define the concepts being used. Hence, there is a need to define the field of the semantic meaning of certain basic (most widespread) lexemes in the area of morality. "The meaning of signs," as noted by Zdzisław Aleksander, "completes the context of their use. The use of a word in practice constitutes its meaning. What is not revealed in the signs can be seen when they are applied. In order to see how a person understands a given word, it is necessary to examine how it is used in specific situations." 11 This legibility of the language is essential, even fundamental, because "we use the same words and apply the same signs, and yet we do not understand each other at all." 12 It seems that what used to be obvious and imperatively binding until recently has been deconstructed and individualized today. Axiological blurring (i.e., disturbance of the general theory of signs) is becoming an increasingly common fact.

An analysis of the lexis reveals changes in the area of morality, because they are first reflected in language and only then in attitudes. ${ }^{13}$ The transformations that are taking place lead to an intergenerational conflict in three areas: that of values, that of beliefs and that of interests. ${ }^{14}$ The Christian understanding of values should be considered on three levels: supernatural values (truths of faith - rationally unverifiable), revealed values (directly relating to man and his being - having an ontological and

Listu\%20do\%20Rzymian\%201-8.pdf?sequence=1\&isAllowed=y (retrieved on May 1, 2021). The previous term "anthropology" - as used in Paul's vision of a Christian - was replaced by the neologism "christianology." Since a Christian is ontically a "new creature," the science that treats of him should also have a name appropriate to its subject. Paul's phrases "living in Christ," "conforming to Christ" or "being in Christ" will not always reflect the emerging biblical tension between "being" and "becoming." The dynamism of "being" (ontic-essential layer) being presented is understood as a permanent "becoming" (existential layer). Focusing on this layer of Paul's Christianity seems to be of the utmost importance, since a moral dimension without an ontic basis would have no raison dêtre.

11 Z. Aleksander, Szansa, p. 85.

12 W. Cichosz, Metodologia. Elementarz Studenta, Gdańsk 2000, p. 7, http:// cichosz.pl/wp-content/uploads/2019/01/ksiazka-1.pdf (retrieved on May 16, 2021).

13 Cf. J. Mariański, Socjologia moralności, Lublin 2006.

14 Cf. M. Ossowska, Normy moralne, Warsaw 1985. 
ethical nature, e.g. human sinfulness, the necessity of redemption, God's judgment, the Decalogue, the Sermon on the Mount, the sacrament, the Church, and the ultimate goal), and the values that play the role of the Christian meaning in human life, culture and history. The inculcation of the above values is conducive to the implementation of both the concept of the human person and the choice of means capable of achieving internal unity. This is why the contribution of Christian thought and biblical values plays such a significant role. The purpose of transmitting these values is to adopt them and grow in them. As early as the first centuries of Chris-

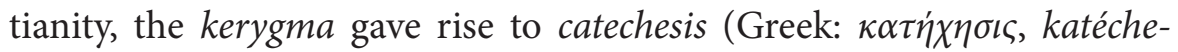
sis), that is instruction on the sacraments, parenesa (Greek: $\pi \alpha \rho \alpha i v \varepsilon \sigma \iota \varsigma$, parainesis), that is practical teaching of a moral character, and didaskalia (Greek: $\delta \iota \delta \alpha \sigma \kappa \alpha \lambda i \alpha$, didaskalía), that is a deeper depiction of the mysteries of faith. ${ }^{15}$

In this context, defining morality as a system of ethical values postulated by a person (or group of people) and followed in social life makes it necessary to integrate in this area - as Pope Francis notes in Christus vivit - "the knowledge of head, heart and hands." ${ }^{16}$ It combines the aforementioned dimensions concerning the "experience of the kerygma, wideranging dialogue, interdisciplinary and cross-disciplinary approaches, the promotion of a culture of encounter, the urgency of creating networks and an option in favour of those who are least, those whom society discards." ${ }^{17}$ Thus, morality presents itself as a set of beliefs and attitudes, statements, assessments and norms that (at least in the eyes of its supporters or followers) constitute a coherent, comprehensive picture of reality (what exists), ordering (evaluating and normalizing) behavior towards oneself and the environment. This meaning is assumed by such terms as "ethics" and "morality" in the papal documents being analyzed, where these terms appear 3 and 5 times, respectively, in Francis's Christus vivit and 3 and 25 times, respectively, in St. John Paul II. ${ }^{18}$ The above lexical and substantive remarks should be borne in mind when the proposition of Christ's

${ }^{15}$ Cf. R. Murawski, Historia katechezy. Katecheza w pierwszych wiekach, part I, Warsaw 2011.

16 Francis, Christus vivit, no. 222.

17 Ibid.

18 Cf. Z. Marek, Podstawy wychowania moralnego, Kraków 2005, pp. 29-33. 
morality is first viewed through the prism of the law as an educator, then through the evangelical adoption in faith, and finally in the context of the Christian heritage of freedom.

\section{THE LAW AS AN EDUCATOR - PARENETIC TESTAMENTAL INTEGRITY}

The Bible plays a fundamental role in inspiring moral education ${ }^{19}$ and shaping the personality of a human being. ${ }^{20}$ It is a light that shows the way (cf. Ps 119:105), a warming fire and a crushing hammer (cf. Jer 23:29), milk for food (cf. Heb 5:13-14), food of strength and sword in battle (cf. Eph 6:17), and a revealing mirror (cf. Jas 1:23-25). ${ }^{21}$ In the history of salvation, God gradually reveals Himself to man, wanting to properly prepare him for the fullness of revelation in the person of Jesus Christ ${ }^{22}$ : "For God so loved the world that he gave his only Son, that whoever believes in him should not perish but have eternal life" (Jn 3:16). Thus, the aim of moral education - both in the Old Testament and in the New Testament is to open the human heart to the word of God, which teaches him about the fear of God, this in turn being the beginning of wisdom. ${ }^{23}$

One should note that for the followers of Judaism and Christians, the Bible is a collection of sacred texts that were written "from the time of Moses's activity in the fifteenth century BC to the end of the first century AD." ${ }^{24}$ They are the scriptures that give testimony of God's revelation to the Israelites, culminating in Jesus Christ: the fullest and final Word spoken by God to man. ${ }^{25}$ The Bible, as the Word of God, is therefore seen by believers as the major form of communicating God's truth to people. It shows the bond that connects God the Creator with His creation. Hence,

19 Cf. B. Adamczyk, Model pedagogii Jezusa w przekazie biblijnym, Kraków 2008, p. 26.

20 Cf. M. Finke, Pedagogika wiary, Poznań 1996, pp. 100-102.

${ }^{21}$ Cf. W. Cichosz, Pedagogia wiary, p. 151.

${ }^{22}$ Cf. B. Adamczyk, Model pedagogii, pp. 94-95.

23 Cf. R. Rubinkiewicz, "Rodzina jako środowisko wychowawcze," in: Biblia o rodzinie, ed. G. Witaszek, Lublin 1995, p. 43.

${ }^{24}$ T. Jelonek, Biblia a nauka. Czy nauka sprzeciwia się Biblii?, Kraków 2005, p. 5.

25 Cf. G. Szamocki, Motyw bramy w Nowym Testamencie. Przyczynek do teologii biblijnej, Pelplin 2001, pp. 149-151. 
a comprehensive understanding of the history of the Old Testament and the New Testament is of fundamental importance. It is difficult to show the fullness of the New Testament without revealing it gradually and evolutionarily in the Old Testament. Likewise, the Old Testament would be incomprehensible without a proper study of the New Testament. ${ }^{26}$ The core of both Books is the Savior repeatedly announced in the Old Testament, who is fully revealed only in the New Testament. According to the maxim of St. Gregory the Great (540-604), Divina eloquia cum legente crescunt - the words of God "grow with the one who reads them."27 This amazing power of the Bible stems from the fact that its primary author is God Himself. For, as it is emphasized in the Dogmatic Constitution Dei verbum, "those divinely revealed realities which are contained and presented in Sacred Scripture have been committed to writing under the inspiration of the Holy Spirit [...] they have God as their author and have been handed on as such to the Church herself." ${ }^{28}$

In the pages of the Bible, God appears as the Educator of the Chosen People. Not only does He enter into a covenant, but He also shows man the way of an exemplary life (giving the commandments on Mount Sinai). Just as Sacred Scripture plays an important role in education in faith, it also plays a significant role in the field of moral (parenetic) education. The teaching on the dignity of every human being becomes the basis for action. ${ }^{29}$ It is the theological and religious dimensions of the person (genealogia divina, the God-given element of man's divine sonhood cf. Gen 1:27) that is treated as the foundation of biblical parenetic pedagogy. Hence, for many Christians, the Old Testament and the New Testament are an exceptional guide to living in accordance with God's values. Although Judaism can find as many as 613 different principles (the Talmud lists a total of 248 commands and 365 prohibitions), the moral imperatives resulting from the biblical paraenetic education are presented

${ }^{26}$ Cf. J. Stępień, “Słowo objawione w przepowiadaniu Słowa Bożego," Ateneum Kapłańskie 67 (1964) no. 1-2, pp. 32-45.

${ }^{27}$ Gregory the Great, Homiliae in Ezechielem, 1, 7, 8, quoted after: Catechism of the Catholic Church, sec. 94.

${ }^{28}$ Second Vatican Council, Dogmatic Constitution on Divine Revelation: Dei verbum, Rome 1965, no. 11.

${ }^{29}$ Cf. J. Bagrowicz, “Godność osoby fundamentem wychowania," in: Wychowanie personalistyczne. Wybór tekstów, ed. F. Adamski, Kraków 2005, p. 191. 
not so much as detailed rules for a Christian in everyday life, but rather as basic norms and guiding ideas. According to them, what is pleasing to God is good, and "the righteous person will live by his faithfulness" $(\operatorname{Hab} 2: 4) .^{30}$

Interestingly enough, in the New Testament, none of the Evangelists call Jesus an educator. This seems understandable due to the connotations of the term at the time. Pope Francis reminds us that in the school system of antiquity, the pedagogue (Greek: $\pi \alpha \iota \delta \alpha \gamma \omega \gamma o$ $\varsigma$ ) did not perform the function that is assigned to that role today: "At the time he was instead a slave whose task was to accompany the master's son to the teacher and then bring him home again. He was thus to protect him from danger and watch over him to ensure he did not behave badly. His function was rather disciplinary." ${ }^{31}$ And this was the role of the law, too. It was certainly restrictive, but also educational and protective and supportive at the same time. "As long as an heir is underage," writes St. Paul, "he is no different from a slave, although he owns the whole estate. The heir is subject to guardians and trustees until the time set by his father. So also, when we were underage, we were in slavery under the elemental spiritual forces of the world" (Gal 4:1-3).

In the Gospels, Jesus Christ is referred to as the Master, Teacher and Friend. ${ }^{32} \mathrm{He}$ was certainly different from the masters of rabbinical schools of His time. ${ }^{33}$ In His activity, He was not limited by an institution, by time or by a specific group of followers. His pedagogy was carried out in the place of His arrival by reaching out to people and constantly looking for them. It is precisely this dimension that distinguishes the Master of Nazareth from other masters. Jesus is first and foremost an itinerant teacher

${ }^{30}$ Cf. Z. Marek, Podstawy wychowania moralnego, Kraków 2005, p. 35; M. Łobocki, Wychowanie moralne w zarysie, Kraków 2002.

31 Francis, General Audience of August 18, 2021, https://www.vatican.va/content/ francesco/en/audiences/2021/documents/papa-francesco_20210818_udienza-generale. html (retrieved on May 26, 2021). Cf. X. Leon-Dufour, Słownik Nowego Testamentu, Poznań 1990, s. 471. Cf. E. Staniek, Pedagogiczne zasady Mistrza z Nazaretu, Kraków 1995.

32 Cf. B. Adamczyk, Model pedagogii, p. 99.

33 Cf. J. Bagrowicz, "Jezus - Nauczyciel, Wychowawca i Mistrz powołuje uczniów," in: Veritas cum caritate - intellegentia cum amore, ed. Cz. Rychlicki and I. Werbiński, Toruń 2011, pp. 67-82. 
who teaches with His whole life and His every activity. ${ }^{34}$ The history of salvation, therefore, can be divided into two stages: before the coming of Jesus, when the law and commandments became the stance of morality and justification, and after His coming. The earlier times are determined by "being under the law," whereas the New Testament times are about "being in Christ."

\section{EVANGELICAL ADOPTION IN FAITH (TO BE IN CHRIST)}

The aforementioned elements of Gospel morality clearly define the model of a perfect educator (and also that of a pupil) and contribute to the conviction that there is no secure foundation for a human being to realize his or her full and dignified humanity other than the person of Jesus Christ. To live in Christ, as St. John Paul II explains in Redemptor hominis, which was his first encyclical (and, in a way, his policy statement), is primarily to serve man in the entire truth of his life and vocation, because man "is the primary and fundamental way for the Church, the way traced out by Christ himself, the way that leads invariably through the mystery of the Incarnation and the Redemption." 35 These words from 1979 frequently reappear in various forms, both in Parati semper by the same Pope and in Christus vivit by Pope Francis. Christ's way of acting is the same for every person He meets, regardless of the level of physical and mental development and social status of the person with whom He enters into a relationship. Jesus does not limit Himself to teachings, but points to specific examples that can become a model for those who wish to follow Him. It is above all an extreme radicalism, manifested by high demands on those who want to achieve salvation (cf. Mt 17:17; 20, 24-28), but also realism, which in turn enables the practical implementation of the obligations undertaken.

${ }^{34}$ Cf. B. Adamczyk, Model pedagogii, p. 111.

35 John Paul II, Encyclical Letter Redemptor Hominis to His Venerable Brothers in the Episcopate, no. 14, https://www.vatican.va/content/john-paul-ii/en/encyclicals/documents/hf_jp-ii_enc_04031979_redemptor-hominis.html (retrieved on September 16, 2021). 
Following the thought of Eduardo Pironio, Pope Francis describes the tension between radicalism and realism as follows: "Roots are not anchors chaining us to past times and preventing us from facing the present and creating something new. Instead, they are a fixed point from which we can grow and meet new challenges. It does us no good 'to sit down and long for times past; we must meet our culture with realism and love and fill it with the Gospel. We are sent today to proclaim the Good News of Jesus to a new age. We need to love this time with all its opportunities and risks, its joys and sorrows, its riches and its limits, its successes and failures." 36

In view of the above, it can be said that the biblical image of Christ's morality is primarily about experiencing the presence of God who chooses, instructs and guides man. Barbara Adamczyk, author of the book Model pedagogii Jezusa w przekazie biblijnym (The Model of Jesus's Pedagogy in the Biblical Tradition), points to the following elements of Jesus's parenetic activity: dialogue that respects the pupil (master-pupil relationship), path and assistance, and full acceptance of the human being as a person. ${ }^{37}$ Dorota Frączek, on the other hand, emphasizes the following educational values: presence (Christ remains with the disciples from the moment of the Incarnation until His death on the cross; He does not leave them alone), teaching (showing the truth about God and proposing to take a strictly defined path of life), setting standards (primarily concerning the internal disposition), giving advice (usually associated with adopting a specific attitude), assigning tasks (shaping the personality), and exhorting others to follow the path of Jesus (completely changing one's life and following the Divine Master). ${ }^{38}$ The most important element for the development of the human person in the moral order is the inner element, that is, nature and grace. The presence of God recognized by man motivates him to strive for true values (spiritual and eternal) and towards the fullness of humanity. ${ }^{39}$ In turn, the personal experience of God be-

36 Francis, Christus vivit, no. 200.

37 Cf. ibid., pp. 115, 147, 179, 229.

38 Cf. D. Frączek, "Pedagogika Jezusa," Wychowawca 168 (2006) no. 12, pp. 8-9.

39 Cf. R. Buchta, W. Cichosz, A. Zellma, "Religious education in Poland during the COVID-19 pandemic from the perspective of religion teachers of the Silesian Voivodeship," Religions 12 (2021) no. 650, pp. 1-13 (DOI: https://doi.org/10.3390/rel12080650). 
comes a testimony for others and an encouragement to seek Him in one's own life.

\section{THE CHRISTIAN LEGACY OF (AUTONOMOUS) FREEDOM}

The spirit of postmodernity is aptly reflected in the statement of the Second Vatican Council presented in the Pastoral Constitution Gaudium et Spes: "Since all these things are so, the modern world shows itself at once powerful and weak, capable of the noblest deeds or the foulest; before it lies the path to freedom or to slavery, to progress or retreat, to brotherhood or hatred. Moreover, man is becoming aware that it is his responsibility to guide aright the forces which he has unleashed and which can enslave him or minister to him. That is why he is putting questions to himself. The truth is that the imbalances under which the modern world labors are linked with that more basic imbalance which is rooted in the heart of man." ${ }^{40}$ In his encyclical Fides et ratio, St. John Paul II adds that "certain scientists, lacking any ethical point of reference, are in danger of putting at the centre of their concerns something other than the human person and the entirety of the person's life. Further still, some of these, sensing the opportunities of technological progress, seem to succumb not only to a market-based logic, but also to the temptation of a quasi-divine power over nature and even over the human being." ${ }^{11}$

The Letter to the Young People Parati semper by St. John Paul II and the Post-Synodal Apostolic Exhortation Christus vivit by Pope Francis clearly show that the human person realizes his or her vocation through constant self-transcendence towards his or her neighbor, towards the created world, and ultimately towards God. He or she is naturally a being oriented towards direct closeness to the Creator (Latin: desiderium naturale in visionem beatificam). In this dimension of human existence (ge-

40 Second Vatican Council, Pastoral Constitution on the Church in the Modern World: Gaudium et Spes, Rome 1965, no. 9-10.

${ }^{41}$ John Paul II, Encyclical Letter Fides et ratio of the Supreme Pontiff John Paul II to the Bishops of the Catholic Church on the Relationship between Faith and Reason, no. 46, https://www.vatican.va/content/john-paul-ii/en/encyclicals/documents/hf_jp-ii_ enc_14091998_fides-et-ratio.html (retrieved on September 16, 2021). 
nealogy and antropologia divina - the image of the divine sonhood), one should look for the sources and goals of Christian freedom, autonomous freedom, that is, personal freedom (the so-called ontological "freedom to" rather than freedom understood as a social category - the so-called "freedom from"). ${ }^{42}$ Freedom - as the papal statements addressed to young people show - is given to a person as a gift, but at the same time it is presented as a task (the so-called maieutics - becoming a person), and becomes fully Christian through pro-existence, that is, being for others, following the example of Jesus Christ. The direction of freedom is clearly marked by the words of St. Paul: "It is for freedom that Christ has set us free. Stand firm, then, and do not let yourselves be burdened again by a yoke of slavery" (Gal 5:1). Every human person should learn the "human profession." While entering their school building, students of the secondary school in Wadowice - including Karol Józef Wojtyła, later known as St. John Paul II - looked at the sentence of the Roman poet Albius Tibullus: "Casta placent superis. Pura cum veste venite et manibus puris sumite fontis aquam" (God is pleased with what is pure. Come in pure clothing. And with clean hands, draw water from the spring). This invitation to draw from the source is both timeless and universal. However, the question of the theoretical understanding and practical use of this source remains at stake (ad extra or inside - Latin: ad intra). ${ }^{43}$

The process of education is accompanied by the following hierarchy of values: from material through spiritual to absolute ones. The absolute value here is not freedom understood as arbitrariness: individualism, egoism or relativism. It is not the intellect and reason of educational methods and techniques, either. Rather, we are speaking of gaining spiritual freedom, inner freedom through cognition, wisdom and love, and reaching the peaks of external freedom by submitting to the values that ensure the development of the person.

42 The issue of autonomous freedom has been discussed extensively in: W. Cichosz, "Błogosławionego Jana Pawła II pedagogia osobowej wolności autonomicznej w świetle encykliki 'Fides et ratio"' ed. J. Meller, Studia Gdańskie 30 (2012), pp. 217-231, http://studiagdanskie.diecezja.gda.pl/pdf/sg_xxx.pdf (retrieved on July 1, 2021).

43 A. Zellma, R. Buchta, W. Cichosz, "The (non)transgressive character of religious education for children and young people in Polish schools," British Journal of Religious Education 2021, pp. 1-15 (DOI: https://doi.org/10.1080/01416200.2021.1887082). 


\section{CONCLUSION}

Man is capable by nature (in his heart) of recognizing good and evil. Morality is then bound to keeping the Law, which, while being positive, is limited in time. Man's coming to faith causes, as Pope Francis points out, the exhaustion of the Law's propaedeutic value and, thus, gives way to another authority. The Law is still in force (the commandments continue to exist), but it has no justifying power. The one who justifies is Jesus Christ. In this context, it is crucial to answer the question regarding the stage of moral maturation: do I still need the Law (an attitude of fear and enslavement), or perhaps I am already living in the love and freedom of a child of God (hope and joy of salvation). However, these levels of morality cannot, as postulated by St. John Paul II and Francis, be treated as separate or contradictory, because both are necessary. Hence, one cannot reject and despise the commandments and, at the same time, keep them, although they are not absolute, because salvation is in Jesus Christ! "What then? Shall we sin because we are not under the law but under grace? By no means! Don't you know that when you offer yourselves to someone as obedient slaves, you are slaves of the one you obey - whether you are slaves to sin, which leads to death, or to obedience, which leads to righteousness? But thanks be to God that, though you used to be slaves to sin, you have come to obey from your heart the pattern of teaching that has now claimed your allegiance. You have been set free from sin and have become slaves to righteousness" (Rom 6:15-18).

A Christian cannot give up hope - this message of entrustment is offered both by St. John Paul II in Parati semper and by Francis in Christus vivit. "Christ is alive! He is our hope," as Pope Francis writes, "and in a wonderful way he brings youth to our world, and everything he touches becomes young, new, full of life. [...] Christ is alive and he wants you to be alive! He is in you, he is with you and he never abandons you. However far you may wander, he is always there, the Risen One. He calls you and he waits for you to return to him and start over again." ${ }^{4}$ This proposal takes a specific shape. It is not just theoretical, but practical. St. John Paul II and Francis propose a new quality that we constantly find in Jesus Christ:

44 Francis, Christus vivit, no. 1-2. 
"All too often we are conditioned by trivial and fleeting models of life that drive us to pursue success at a low price, discrediting sacrifice and inculcating the idea that education is not necessary unless it immediately provides concrete results. No, education makes us raise questions, keeps us from being anaesthetized by banality, and impels us to pursue meaning in life. We need to reclaim our right not to be sidetracked by the many sirens that nowadays distract from this pursuit. Ulysses, in order not to give in to the siren song that bewitched his sailors and made them crash against the rocks, tied himself to the mast of the ship and had his companions plug their ears. Orpheus, on the other hand, did something else to counter the siren song: he intoned an even more beautiful melody, which enchanted the sirens. This, then, is your great challenge: to respond to the crippling refrains of cultural consumerism with thoughtful and firm decisions, with research, knowledge and sharing." ${ }^{35}$

\section{BIBLIOGRAPHY}

Adamczyk B., Model pedagogii Jezusa w przekazie biblijnym, Kraków 2008.

Aleksander Z., Szansa na międzypokoleniowy dialog w kontekście rozumienia słów z zakresu moralności przez współczesne podmioty edukacyjne, Gdańsk 2009.

Bagrowicz J., "Godność osoby fundamentem wychowania," in: Wychowanie personalistyczne. Wybór tekstów, ed. F. Adamski, Kraków 2005, pp. 179-212.

Bagrowicz J., "Jezus - Nauczyciel, Wychowawca i Mistrz powołuje uczniów," in: Veritas cum caritate - intellegentia cum amore, ed. Cz. Rychlicki and I. Werbiński, Toruń 2011, pp. 67-82.

Balthasar H. U. von, W petni wiary, transl. J. Fenrychowa, Kraków 1991.

Buchta R., Cichosz W., Zellma A., "Religious education in Poland during the COVID-19 pandemic from the perspective of religion teachers of the Silesian Voivodeship," Religions 12 (2021) no. 650, pp. 1-13 (DOI: https://doi.org/10.3390/rel12080650).

Cichosz W., "Biblijne wychowanie parenetyczne. Od pedagogiki do pedagogii," ed. R. Czekalski, Studia Katechetyczne 8 (2012), pp. 243-253, https://bazhum.muzhp.pl/media/files/Studia_Katechetyczne/Studia_Katechetyczne-r2012-t8/Studia_Katechetyczne-r2012-t8-s243-253/Studia_Katechetyczne-r2012-t8-s243-253.pdf (retrieved on September 2, 2021).

Cichosz W., "Błogosławionego Jana Pawła II pedagogia osobowej wolności autonomicznej w świetle encykliki 'Fides et ratio", ed. J. Meller, Studia Gdańskie 30 (2012),

45 Ibid., no. 223. 
pp. 217-231, http://studiagdanskie.diecezja.gda.pl/pdf/sg_xxx.pdf (retrieved on July 1, 2021).

Cichosz W., Lisica J., "Przyczynek do chrystianologii moralnej św. Pawła w świetle Listu do Rzymian 1-8," ed. J. Szulist, Studia Pelplińskie 46 (2013), pp. 31-48, https://depot.ceon. pl/bitstream/handle/123456789/7394/Przyczynek\%20do\%20chrystianologii\%20 moralnej\%20\%C5\%9Bw.\%20Paw\%C5\%82a\%20w\%20\%C5\%9Bwietle\%20Listu\%20 do\%20Rzymian\%201-8.pdf?sequence=1\&isAllowed=y (retrieved on May 1, 2021).

Cichosz W., Metodologia. Elementarz Studenta, Gdańsk 2000, http://cichosz.pl/wp-content/uploads/2019/01/ksiazka-1.pdf (retrieved on May 16, 2021).

Cichosz W., Pedagogia wiary we współczesnej szkole katolickiej, Warsaw 2010.

Finke M., Pedagogika wiary, Poznań 1996.

Francis, General Audience of August 18, 2021, https://www.vatican.va/content/francesco/en/audiences/2021/documents/papa-francesco_20210818_udienza-generale.html (retrieved on May 26, 2021).

Francis, Post-Synodal Apostolic Exhortation Christus Vivit to Young People and to the Entire People of God, Rome 2019, https:/www.vatican.va/content/francesco/en/ apost_exhortations/documents/papa-francesco_esortazione-ap_20190325_christus-vivit.html (retrieved on July 18, 2021).

Frączek D., "Pedagogika Jezusa," Wychowawca 168 (2006) no. 12, pp. 8-9.

Gregory the Great, Homiliae in Ezechielem, 1, 7, 8, quoted after: Catechism of the Catholic Church, sec. 94.

John Paul II, Encyclical Letter Veritatis Splendor Regarding Certain Fundamental Questions of the Church's Moral Teaching, Rome 1993, https://www.vatican.va/content/ john-paul-ii/en/encyclicals/documents/hf_jp-ii_enc_06081993_veritatis-splendor.html (retrieved on September 16, 2021).

John Paul II, Encyclical Letter Redemptor hominis to His Venerable Brothers in the Episcopate, no. 14, https://www.vatican.va/content/john-paul-ii/en/encyclicals/documents/hf_jp-ii_enc_04031979_redemptor-hominis.html (retrieved on September 16, 2021).

John Paul II, Encyclical Letter Fides et ratio of the Supreme Pontiff John Paul II to the Bishops of the Catholic Church on the Relationship between Faith and Reason, no. 46, https://www.vatican.va/content/john-paul-ii/en/encyclicals/documents/ hf_jp-ii_enc_14091998_fides-et-ratio.html (retrieved on September 16, 2021).

John Paul II, Apostolic Letter Dilecti Amici to the Youth of the World on the Occasion of International Youth Year, Rome 1985, https:/www.vatican.va/content/john-paul-ii/ en/apost_letters/1985/documents/hf_jp-ii_apl_31031985_dilecti-amici.html (retrieved on September 16, 2021).

Jelonek T., Biblia a nauka. Czy nauka sprzeciwia się Biblii?, Kraków 2005.

Catechism of the Catholic Church, Washington, DC 2019.

Koszkało M., "Bóg jako źródło moralności. Intuicje św. Augustyna w Wyznaniach 7.10-11 w kontekście dyskusji z tradycją starożytną," Verbum Vitae 39 (2021) no. 3 (DOI: https://doi.org/10.31743/vv.12827).

Leon-Dufour X., Słownik Nowego Testamentu, Poznań 1990.

Łobocki M., Wychowanie moralne w zarysie, Kraków 2002. 
MacIntyre A., Dziedzictwo cnoty. Studium z teorii moralności, Warsaw 1996.

Marek Z., Podstawy wychowania moralnego, Kraków 2005.

Mariański J., Socjologia moralności, Lublin 2006.

Murawski R., Historia katechezy. Katecheza w pierwszych wiekach, part I, Warsaw 2011.

Ossowska M., Normy moralne, Warsaw 1985.

Rubinkiewicz R., "Rodzina jako środowisko wychowawcze," in: Biblia o rodzinie, ed. G. Witaszek, Lublin 1995, pp. 37-46.

Second Vatican Council, Pastoral Constitution on the Church in the Modern World: Gaudium et Spes, Rome 1965.

Second Vatican Council, Dogmatic Constitution on Divine Revelation: Dei verbum, Rome 1965, no. 11.

Staniek E., Pedagogiczne zasady Mistrza z Nazaretu, Kraków 1995.

Stępień J., "Słowo objawione w przepowiadaniu Słowa Bożego," Ateneum Kapłańskie 67 (1964) no. 1-2, pp. 32-45.

Szamocki G., Motyw bramy w Nowym Testamencie. Przyczynek do teologii biblijnej, Pelplin 2001.

Tykarski S., "The evolution of modern marriage: from community to individualization. Theological reflection," Cauriensia. Revista anual de Ciencias Eclesiásticas 14 (2019), pp. 581-592. DOI: https://doi.org/10.17398/2340-4256.14.581.

Wanat Z., Hipokrates i sumienie. Teologiczny aspekt formacji moralnej pracowników stużby zdrowia, Pelplin 2019.

Zellma A., Buchta R., Cichosz W., "The (non)transgressive character of religious education form children and young people in Polish schools," British Journal of Religious Education 2021, pp. 1-15. DOI: https://doi.org/10.1080/01416200.2021.18 87082 . 
